13. Browse S. Cognitive Rhetoric : The Cognitive Poetics of Political Discourse. Amsterdam ; Philadelphia : John Benjamins Publishing Company, 2018. $247 \mathrm{p}$.

14. Denham A. Metaphor and Moral Experience. Oxford : Clarendon Press, 2000. 376 p.

15. Fahnestock J. Rhetoric in the Age of Cognitive Science. The Viability of Rhetoric / ed. R. Graff. New York: State University of New York Press, 2005. P. 159-179.

16. Fauconnier G. \& Turner M. Rethinking Metaphor. Cambridge Handbook of Metaphor and Thought / ed. R. Gibbs. New York : Cambridge University Press, 2008. P. 53-66.

17. Lakoff G. The Contemporary Theory of Metaphor. Metaphor and Thought : 2nd edition. New York : Cambridge University Press, 1993. P. 202-255.

18. Lakoff G. \& Johnson M. Metaphors We Live By. Chicago : University Of Chicago Press, 1980. 256 p.

\title{
ДЖЕРЕЛА
}

NewsChurch - Синодальний інформаційно-просвітницький відділ УПЦ (http://news.church.ua/).

CerkvaInfo - Офіційний сайт Української Православної Церкви Київського Патріархату (http://www.cerkva.info/).

$$
\begin{aligned}
& \text { Дата надходження до редакції - 12.10.2018 p. } \\
& \text { Дата затвердження редакцісю - 19.11.2018 p. }
\end{aligned}
$$

УДК $81 ’ 42: 17.022 .1$

DOI: https://doi.org/10.17721/APULTP.2018.37.105-124

Olga M. Pliasun

\section{THE CATEGORY OF IMAGE IN LINGUISTIC DISCOURSE}

Abstract. The article aims to give a comprehensive account of innovative theoretical developments in the field of linguistic imageology. The main objective of the paper is the linguistic analysis of the category of 
image, its major features and characteristics. Quite recently, considerable attention has been paid to the problem of image-making in Slavic and West European linguistics, which is evidenced in numerous scientific investigations related to this topic. Current research is focused on the analysis of linguistic mechanisms of image making, investigation of the socalled "influential potential" of image, its ability to form new social meanings and tendencies. This study examines the category of image in cognitive-discursive, phonological, lingvocultural and lingvosemiotic facets. The author defines image as a specific means of communication; a kind of "code", a set of meanings, symbols that can be read on verbal and non-verbal levels. In the process of subject-subject interaction, this "code" is read by recipients. Hence, according to author's beliefs, such an interpretation of the category allows scientists to expand the boundaries of image research and consider the problem of image within new linguistic directions, i.e. communicative linguistics and text linguistics. The author explains that the image phenomenon has an ambiguous nature and stereotypical character. It is stated that an obligatory condition for the formation of an effective image, in particular state image, is taking into account stereotypical characteristics of the image object which have been established in a certain society. In this paper, the author investigates a number of conceptually important for linguistic imageology terms. Particular attention is paid to linguistic comprehension of the concepts of image plot, image text, language image, correct language behavior etc. The proposed study emphasizes a special role of estimation as one of the key characteristics of image media texts, as it is the basis of any image constructed by media. It is proved that estimation creates an evaluative attitude to the reported information. At the same time, attention is focused on the essential role of the prosodic components of speech (i.e. increase and decrease of voice, change the pace of speech, timbre, pause etc.) in the process of shaping a political image. A conclusion is made about a great suggestive potential of image, which determines the prospects of research of this category in neurolinguistic aspect. The author's view is that a new stage of research in the field of linguistic imageology may be an analysis of the image phenomenon in mass media discourse, as the basic category of an innovative humanitarian discipline - media linguistic imageology. In Ukrainian linguistic science this aspect of research is just beginning to develop and therefore requires detailed study and analysis. To the author's best knowledge, only one study in Ukraine has come up with this issue. This paper clearly shows that investigating image issues in terms of medialingvoimageology has the greatest scientific perspective, which is 
justified by the possibility of studying the verbal nature of image with the involvement of alarge arsenal of knowledge from various research areas.

Key words: lingvoimageology, medialingvoimageology, category of image, linguistic aspects of image research, image text, image plot, language image.

Information about author: Pliasun Olga Mykolayivna postgraduate student, assistant of the department of stylistics and language communication; Institute of philology; Kyiv national Taras Shevchenko university.

E-mail: olga_2511@ukr.net.

Плясун О.М.

\section{КАТЕГОРІЯ ІМІДЖУ В ЛІНГВІСТИЧНОМУ ДИСКУРСІ}

Анотація. Стаття присвячена аналізу перспективних напрямів іміджевих досліджень в українській та зарубіжній лінгвістиці. Авторську увагу закцентовано на сучасних тенденціях розвитку лінгвоіміджелогї як актуальної неолінгвістичної парадигми, що вивчає мовні механізми іміджетворення, "впливовий потенціал" іміджу, його здатність формувати нові соціальні смисли й рефлексії. Центральним поняттям лінгвістичної іміджелогії $\epsilon$ категорія іміджу, яку автор розглядає в когнітивно-дискурсивному, фонологічному, лінгвокультурологічному та лінгвосеміотичному аспектах. $У$ статті імідж визначено як специфічний засіб комунікащії; своєрідний "код", набір смислів, символів, щзо можуть бути прочитані на вербальному й невербальному рівнях. У прочесі суб'єкт-суб'єктної взаємодії ией "код" зчитується реципієнтами учасниками комунікації. Відповідно, на переконання автора, така інтерпретація категорії дозволяє розширити межі іміджевих досліджень $і$ розглядати ї в аспекті неонапрямів мовознавства нових підходів до комунікативної лінгвістики та лінгвістики тексту. Встановлено, що феномен іміджу має двозначну природу та стереотипний характер. Висловлено тезу про те, щуо необхідною умовою формування ефективного іміджу, зокрема державного, $\epsilon$ врахування сформованих у суспільстві стереотипних характеристик об'єкта іміджування. Проаналізовано ряд концептуально важливих для лінгвістичної іміджелогії термінопонять. Особливу увагу 
Актуальні проблеми української лінгвістики: теорія і практика

приділено лінгвістичному осмисленню понять "іміджевий сюжет", "іміджевий текст", "мовний імідж", "правильна мовна поведінка" та iH.

У пропонованому дослідженні наголошується на оцінності як одній із ключових характеристик іміджевих медійних текстів, адже в основі будь-якого іміджу, конструйованого засобами масової комунікації, лежить саме оцінка, яка створює авторське ставлення до повідомлюваної інформачї. Водночас акцентується увага на суттєвій ролі просодичних компонентів мовлення (тону, темпу, тембрового забарвлення, паузаціі) у прочесі формування політичного іміджу. Робиться висновок про великий сугестивний потенціал іміджу, щуо зумовлює перспективність дослідження иієї категорії у нейролінгвістичному аспекті.

Новим етапом досліджень у галузі лінгвістичної іміджелогіі, на думку автора, може бути аналіз феномену іміджу у дискурсі масмедіа - як базової категорї новітньої гуманітарної дисципліни медіалінгвоіміджелогї. В украӥнській лінгвістичній науці ия галузь тільки починає формуватися $і$ тому потребує детального вивчення. На переконання автора, вивчення іміджевої проблематики в медіалінгвоіміджелогї має найбільшу наукову перспективу, щуо аргументується можливістю студіювання вербальної природи іміджу із залученням великого арсеналу знань із різних дослідницьких напрямів.

Ключові слова: лінгвоіміджелогія, медіалінгвоіміджелогія, категорія іміджу, лінгвістичні аспекти дослідження іміджу, іміджевий текст, іміджевий сюжет, мовний імідж.

Інформація про автора: Плясун Ольга Миколаӥвна - аспірант, асистент кафедри стилістики та мовної комунікації; Інститут філологї; Київський національний університет імені Тараса Шевченка.

Електронна адреса: olga_2511@ukr.net.

Плясун О.Н.

\section{КАТЕГОРИЯ ИМИДЖА В ЛИНГВИСТИЧЕСКОМ ДИСКУРСЕ}

Аннотация. Статья посвящена анализу перспективных направлений имиджевых исследований в украинской и зарубежной лингвистике. Авторское внимание сакцентировано на современных 
Випуск XXXVII

тенденциях развития лингвоимиджелогии как актуальной неолингвистической парадигмы, которая изучает языковые механизмы создания имиджа, "влиятельный потенцииал" имиджа, его способность формировать новые сочиальные смысль и рефлексии. Центральным понятием лингвистической имиджелогии является категория имиджа, которую автор рассматривает в когнитивнодискурсивном, фонологическом, лингвокультурологическом и лингвосемиотическом аспектах. $B$ статье имидж определен как специфическое средство коммуникации; своеобразный "код", набор смыслов, символов, которые могут быть прочитаны на вербальном и невербальном уровнях В процессе субъект-субъектного взаимодействия этот "код" считывается реципиентами участниками коммуникации. Соответственно, по убеждению автора, такая интерпретация категории позволяет расширить границь имиджевых исследований и рассматривать ее в аспекте неонаправлений языкознания - новых подходов к коммуникативной лингвистике и лингвистике текста. Определено, что феномен имиджа имеет двусмысленную природу и стереотипный характер. Высказан тезис о том, что необходимым условием формирования эффективного имиджа, в частности государственного, является учет сложившихся в обществе стереотипных характеристик объекта имиджирования. Проанализирован ряд концептуально важных для лингвистической имиджелогии терминопонятий. Особое внимание уделено лингвистическому осмыслению понятий "имиджевый сюжет", "имиджевый текст", "языковой имидж", "правильное речевое поведение" и др.

В предлагаемом исследовании подчеркивается особая роль оценочности как одной из ключевых характеристик имиджевыхмедийных текстов, ведь в основе любого имиджа, конструированного средствами массовой коммуникации, лежит именно оценка, которая создает оценочное отночение к сообщаемой информации. $B$ то же время акцентируется внимание на сущуественной роли просодических компонентов речи (тона, темпа, тембровой окраски, паузации) в процессе формирования политического имиджа. Делается вывод о большом суггестивном потенциале имиджа, что обуславливает перспективность исследования этой категории в нейролингвистическом аспекте.

Новым этапом исследований в области лингвистической имиджелогии, по мнению автора, может быть анализ феномена имиджа в дискурсе масс-медиа - как базовой категории новейшей 
Актуальні проблеми української лінгвістики: теорія і практика

гуманитарной дисчиплины -медиалингвоимиджелогии. В украинской лингвистической науке эта отрасль только начинает формироваться и потому требует детального изучения. По мнению автора, изучение имиджевой проблематики в медиалингвоимиджелогии имеет наибольшую научную перспективу, что аргументируется возможностью изучения вербальной природы имиджа с привлечением большого арсенала знаний из разных исследовательских направлений.

Ключевые

слова:

лингвоимиджелогия,

медиалингвоимиджелогия, категория имиджа, лингвистические аспекты исследования имиджа, имиджевый текст, имиджевый сюжет, языковой имидж.

Информация об авторе: Плясун Ольга Николаевна - аспирант, ассистент кафедры стилистики и языковой коммуникации; Институт филологии; Киевский наџиональный университет имени Тараса Шевченко.

Электронный адрес: olga_2511@ukr.net.

Lingvoimageology, or linguistic imageology is, from our perspective, one of the most promising research areas of modern humanities and, primarily, neolinguistics. Lingvoimageology mainly focuses on the analysis of linguistic mechanisms ofimage making and the study of the so-called "influential potential" of image (the term by T. Kozhevnikova [12, p. 58]), its ability to form new social meanings and tendencies.

The topicalityof the above-mentioned problem is evidenced in the innovative works of numerous foreign and Ukrainian scientists, in particular I. Mogor-Ivan, M. Priezler (University of Galati, Romania) [17], Sh. Khairov (University of Glasgow, Scotland) [10], M. Zelenka (Constantine the Philosopher University in Nitra, Slovakia) [32], M. Katynska (Amur State University, Russian Federation) [7, 8, 9], O. Kubryakova (Institute of Linguistics, Russian Academy of Sciences, Russian Federation) [13], O. Osyetrova(SiberianFederalUniversity,

RussianFederation)[19],A. Prokhorov(DerzhavinTambovStateUniver sity, RussianFederation) [22],S. Kamalova (Moscow State Institute of International Relations, Russian Federation) [6], O. Tomberg (Ural Federal University, Russian Federation) [29], Yu. Makarovets (Nizhyn Gogol State University, Ukraine) [16], O. Ivantsiv ( Ivan 
Franko National University of Lviv, Ukraine) [5], I. Lysychkina (Academy of the Interior Troops of the Ministry of Int ernal AffairsofUkraine, Ukraine) [15], T. Zabolotna(State Higher Educational Institution "Pereyaslav-Khmelnytsky State Pedagogical University named after Gregory Skovoroda", Ukraine) [31], A. Moroz (National Pedagogical Dragomanov University, Ukraine) [18], L. Ivanova (Kherson State University, Ukraine) [4] etc.

Investigations of linguistic features of constructing an image are actively conducted in foreign linguisticsin the last decade (20072017) (works by I. Mogor-Ivan, M. Priezler [17], Sh. Khairov [10], M. Zelenka [32] etc.

In parallel, surveys in linguistic imageology appear in Slavic linguistics (works by T. Kozhevnikova [12], O. Shnyakina [23], M. Katynska [7, 8, 9], A. Prokhorov [22], E. Frolova [2], O. Osyetrova [19], Yu. Lozovskiy [14], O. Goloshumova [3], O. Ponomareva [20], L. Yegorova [30], O. Kubryakova [13], N. Koval [11], O. Ivantsiv [5], Yu. Makarovets [16], I. Lysychkina [15], T. Zabolotna [31], A. Moroz [18], L. Ivanova [4] etc.

We note thatthe category of image as the central notion of linguistic imageologyis studied by linguists in many ways. Thus, the linguist $\mathrm{O}$. Ivantsiv distinguishes and systematizes the following aspects of scientific research in this field:

- cognitive-discursive, within which the research attention, in our opinion, deserve the works of T. Kozhevnikova [12], M. Katynska [7, 8, 9], A. Prokhorov [22], I. Sushnenkova [28], O. Sidak [27], E. Frolova [2], I. Lysychkina [15], Yu. Lozovskiy [14] etc;

- phonological, presented in research by N. Koval [11], O. Goloshumova [3], L. Postnikova [21] and others;

- lingvocultural, represented in scientific research by O. Ponomareva [20], V. Dauletova [1] etc;

- lingvosemiotic (scientific research by O. Kubryakova [13] and others.

In the cognitive-discursive paradigm of linguistic research image is analyzed as a way of categorizing and conceptualizing the world. In this sense, image is a cognitive category, a carrier of cognition; accordingly, constructing and modeling the image, we 
discover the world. Cognitive linguistics explores image as a mental model that reflects certain characteristics of an image-raising object and allows to obtain information about it [7, p. 62].

Given the dual nature of the analyzed phenomenon - as an element of the verbal and non-verbal (sign) system, as well as its conceptual semantics, the cognitive-discursive angle of image research seems to be one of the most promising.

Innovative approach to the interpretation of the phenomenon of image realizes in her scientific research linguist M. Katynska [7], analyzing this category through the prism of the theory of prototypes (E. Rosh, L. Wittgenstein, etc.).

An important achievement of cognitive image research is the discovery of ambiguity of this category. Indeed, we have no doubt that any image has a verbal and non-verbal representation. Accordingly, the non-verbal part of image is classified in cognitive linguistics as a mental model, while verbalized image is considered a sign model [8].

Thus, modeling the verbal component of image will allow "to change the attitude of the mass audience to the image carrier", which will potentially lead to "further correction of the recipients' behavior" and "decision-making in favor of a particular product, service, etc."[8].

Note that in many scientific works devoted to the problem of image scholars emphasize the stereotypical nature of this phenomenon. From the point of view of cognitive linguistics, the importance of studying the stereotypical characteristics of image as a prototypical category is determined by their ability to become prototypes of components that structure image [8].

Thus, stereotypes can be considered as original prototypes of image. However, we emphasize that the concepts "stereotype" and "image" are not synonymous: a stereotype is a relatively stable view of something, it has a static nature. In contrast, image is a dynamic phenomenon: if certain features or characteristics of its carrier are changing, the image itself is also changing. On the other hand, it is logical to assume that stereotypical beliefs to a large extent influence the process of constructing an image. Hence, determination the main 
stereotypical image characteristics is a prerequisite for the formation of an effective image. In particular, we are convinced that while working on creating an external and internal image of Ukraine, it is important to take into account positive state stereotypes already formed in society.

Another representative of the cognitive-discursive aspect of image research, linguist E. Frolova, analyzes the category of image as a phenomenon of political linguistics [2]. Considering the main communicative strategies for forming the image of a regional leader, the scientist quite rightly notes that image is one of the most effective means of influencing mass consciousness [2].

Such a peculiarity of image is explained, in our opinion, by a significant manipulative potential of this phenomenon, its stereotypical nature, inclusion in the mass media information space, which causes an increase in interest in the image issues in the field of political linguistics, especially during election campaigns and sociological surveys.

At the same time, modern linguistic investigations in this area actively develop the conceptual apparatus of linguistic imageology. For instance, the researcher E. Frolova introduces into the scientific circle the concept of the image plot- "agenre of a PR-text, prepared by the press service of the head of the region or by the journalists themselves, which presents a socially significant problem, where the facts, the very problem, as well as a view on this problem contribute to the formation of a positive image of a certain regional leader" [2].In our view, understanding the basic principles of creating image plots is necessary for constructing a successful and effective image.

The incorporation of the linguistic component into a general image problem also suggests the need for a study of the concept of "language image", proposed by O. Osyetrova [19]. The scientist analyzes the above-mentioned concept in the context of the development of lingvopsychology and links it with Yu. Karaulov's notion of language personality as "a personality, which is manifested in language (texts) and reconstructed in its main features on the basis of linguistic means" [19, p. 80]. And this point of view is, to our mind, quite correct, as any image has a verbal expression. 
Hence, language as the main verbalizer of consciousness constructs the image and affects it.

In this sense, language image, according to O. Osyetrova, is an external part of the linguistic person, its "façade", open to the public [19]. The investigator rightly argues that the mastery of the art of constructing a positive language image is important for "correct language behavior", that is, the ability to speak a literary language, to use etiquette formulas, to prove yourself as a cooperative type of language personality, to correctly conduct a conversation, etc [19, p. 81].

The author's thesis about close connection between image and language personality also seems logical. The scientist postulates that the more exactly they coincide, the more natural the communicative game will be. At the same time, the more an image of a person differs from its language behavior, the more deformed becomes the image mask [19, p. 81]. Indeed, the image of a personmust correspond to his/her true nature; in the other case, the so-called "gap" between the ideal and the real image will be definitely noticed, which will undermine the potential impact on the audience.

In turn, the linguist Yu. Lozovskiy'sresearchthesisisdevoted to the analysis of linguistic means for creating a well-known person's image [14]. In his work, the author interprets the investigated phenomenon as "one of the means of communication, which, with the help of purposefully created and emotionally colored images having the character of a stereotype, translates information about a real person based on the needs of mass consciousness" [14, p.4].

It should be emphasized that in Yu. Lozovskiy's interpretation of image the definition of the above-mentioned phenomenon as $\boldsymbol{a}$ specific means of communication is innovative for modern linguistics. We fully agree with the author's position, as any image is a kind of "code", a set of meanings, symbols whichcan be read at verbal and non-verbal levels. Accordingly, in the process of subjectsubject interaction, this "code" is read by recipients - the participants of the communication; hence, image can be defined as a unique means of communication. In our opinion, such an interpretation of the studied category makes it possible to expand the scope of image 
research and consider it in the aspect of new directions of modern linguistics, in particular, communicative linguistics and text linguistics.

In Yu. Lozovskiy's interpretation of image a statement about the importance of assessment as the basis for building an image and creation a certain evaluation attitude also seems logical [14, p.4].

It is worth noting that for our investigation this thesis is relevant, since the analysis of media publications devoted to the image of Ukraine proves that estimation is one of the key characteristics of such texts.

In modern linguistics, the category of image is also studied in the phonological aspect, where the phonetic characteristics of the image are in the center of attention. In particular, O. Goloshumova's thesis is devoted to the study of the role of intonation and other linguistic means in shaping and optimizing the image of the political leader [3]. In her work, the scientist analyzes intonational means of language, which, in combination with lexical-syntactic and stylistic means, carry out the function of influence and promote the construction of an effective political image [3].

Having conducted a comprehensive audit and functional analysis of the speeches of American political figures, the author concludes that it is the language that most successfully transfers the image of a politician to the audience and allows him/her to achieve his/her goal and gain credibility [3]. It is to be noted that the analyzed by $\mathrm{O}$. Goloshumova phonetic characteristics of image are quite actively used in modern political communication. Increase and decrease of voice, change the pace of speech, timbre, pause - all these phonetic means are successfully used by politicians in their speeches.

Meanwhile, the results of the phonetic research conducted by N. Koval point out that prosodic characteristics of a person are an important part of image technologies used by image makers due to their ability to "overcome the thresholds of audience's perception" and be "in advance doomed to success" [11]. Undoubtedly, this fact attests to great suggestive potential of image, the need for its study 
within the newest linguistic directions, in particular, neurolinguistic programming.

In the lingvocultural discourseimage is explored by O. Ponomareva [20]. The scientist examines the category of image in correlation with language and culture, emotion and cognition. We believe that nowadays image is a complex sociocultural phenomenon, an important element of the formation of a national identity, therefore, lingvocultural aspect of image investigations is, in our opinion, also worthy of research attention.

Nonetheless, L. Yegorova's PhD thesis is significant for the development of the terminological apparatus of lingvoimageology. In her investigation, the scientist introduces the concept of image text [30]. According to L. Yegorova, image text is "a text phenomenon of media discourse, a carrier of a special type of social information imageinformation, verbalized by adequate means" [30, p.6].

L. Yegorova analyzes the concept of image as a linguistic and sociocultural category of media discourse, which has a field structure. Accordingly, in this structure the researcher allocates the core and periphery. The core of the image is characterized by a maximum concentration of signs, and the periphery of the imageis characterized by an incomplete set of signs [30, p.10-11].

We note that lingvosemiotic aspect of image research is quite new in modern linguistics. For instance, O. Kubryakova's scientific investigation is devoted to the analysis of sign nature of image [13]. Considering image as a sign, the researcher rightly observes that for its definition "it is important to establish in relation to which object is it a sign - in relation to such "an empirical object" as a person, or such an ideal object as his/her image (or his/her essence - character, moral features, that is, something from the sphere of abstract and ideal)" [13, p.6]. According to O. Kubryakova, image is called to replace a real object or person in other people's perception [13, p.9]. Consequently,one of the dominant functions of image in all the analyzed approaches is a substitutive function.

Therefore, image can be considered one of the most universal categories of modern humanities. It is an interdisciplinary phenomenon, which is the subject of analysis of many scientific 
directions. Since the interpretation of a concept depends on the goals and objectives of a particular science, any interpretation of this category is of a sectoral nature. However, in our view, linguistics has the most scientific perspective in the study of image issues as it analyzes verbal nature of image and uses a large arsenal of knowledge from various research areas.

In our opinion, a new stage in image investigations can be the analysis of this phenomenon in media linguistic discourse as the basic category of modern discipline - medialingvoimageology new paradigm of modern linguistics, which is now at the stage of formation and therefore needs to be studied in detail. In fact, in modern sciencemedialingvoimageologyis represented only by scientific investigations of A. Shylina [24, 25, 26].

To our mind, image in the framework of the outlined issues can be analyzed in broad and narrow terms.

Thus, in a broad term, we interpret image as a thought of the object (subject) which is intentionally formed in mass or individual consciousness.

In a narrow sense, we consider this term within the framework of media linguistic perspective, where we define image as one of the central concepts of modern media linguistics; the result of the work of media aimed at constructing in mass consciousness an emotionally-evaluative thought about an object (subject) with a clearly expressed semantics (positive / negative), in the process of which media use effective linguistic means of image building, i.e. writing and distribution of image texts, plots, accumulation ofaffective statements, emotionally-evaluative lexemes, emotional subjective judgments, usage of suggestive neurolinguistic technologies, etc.

\section{REFERENCES}

1. Dauletova V. Verbal means of creating an autoimage in political discourse (on the material of Russian and English biographical prose) [Verbalnyie sredstva sozdaniya avtoimidzha v politicheskom diskurse (na material russkoy i angliyskoy biograficheskoy prozyi)]: abstract of thesis for the PhD degree, specialty 10.02.20 "Comparative-historical, typological and comparative linguistics". Volgograd, 2004. 16 p. 
2. Frolova E. Communicative strategies for the formation of the image of a regional leader in electronic media [Kommunikativnyie strategii formirovaniya imidzha regionalnogo lidera $\mathrm{v}$ elektronnyih media]: author. dis. for the $\mathrm{PhD}$ degree, spec. 10.02.01 "Russian language". Omsk, 2007. $24 \mathrm{p}$.

3. Goloshumova $\mathrm{O}$. The role of intonation and other language means in shaping and optimizing the image of a political leader (on the material of public speeches by American politicians] [Rol intonatsii i drugih yazyikovyih sredstv $\mathrm{v}$ formirovanii i optimizatsii imidzha politicheskogo lidera (na materiale publichnyih vyistupleniy amerikanskih politicheskih deyateley)]: abstract of thesis for the $\mathrm{PhD}$ degree, specialty 10.02.04 "Germanic Languages". M., 2002. 16 p.

4. Ivanova L. Europe in N.S. Gumilev's perception (lingvoimagological aspect) [Evropa v videnii N.S. Gumileva (lingvoimagologicheskiy aspekt)]. Scientific Bulletin of Kherson State University. Series "Linguistics". 2013. Issue 18. P. 183-187.

5. Ivantsiv O. Cognitive-discursive fundamentals of corporate image formation (based on the English language press releases of international cosmetic companies) [Kohnityvno-dyskursyvni osnovy formuvannia korporatyvnoho imidzhu (na materiali anhlomovnykh pres-reliziv mizhnarodnykh kosmetychnykh kompanii)]. Dissertation for the for the $\mathrm{PhD}$ degree. Lviv, 2015. 225p.

6. Kamalova D. The image of Palestinians in the Israeli-Palestinian conflict [Imagologicheskiy obraz palestintsa $\mathrm{v}$ palestino-izrailskom konflikte]. Philological sciences at MGIMO. 2017. № 12 (4). P. 1-9.

7. Katynskaya M. The category of image: approaches to consideration [Kategoriyaimidzha: podhodyi k rassmotreniyu]. Theoretical and applied linguistics. Blagoveshchensk, 2015. Volume 1. № 3. P. 61-70.

8. Katynskaya M. Image as a prototypical category [Imidzh kak prototipicheskaya kategoriya]. Bulletin of the KSU. 2016. № 3.

9. Katynskaya M. Model of the verbalized image of the Australian education [Model verbalizovannogo imidzha avstraliyskogo obrazovaniya]. Modern problems of interaction of languages and cultures: materials of the Intern. Forum 14-15 dec. 2012. Blagoveshchensk: Amur State University Publishing House. 2012. Part 1. P. 127-134.

10. Khairov Sh. The alphabet in linguistic imagology: ideological and aesthetic values in the disputes on the pre-reform cyrillic letters in Russia before and after 1918 [Grafika kak object lingvisticheskoy imagologii. O nekotoryih tipah esteticheskih I ideologicheskih otsenok doreformennoy kirillitsyi v Rossii do I posle 1918 g.]. Studi Slavistici XIV. 2017. P. 293-307. 
11. Koval N. Prosodic image characteristics of political oratory (experimental and phonetic study on the material of the British version of the English language) [Prosodychni imidzhevi kharakterystyky politychnoi oratorskoi promovy (eksperymentalno-fonetychne doslidzhennia na materiali brytanskoho varianta anhliiskoi movy)]: abstract of thesis for the $\mathrm{PhD}$ degree, specialty 10.02.04. "Germanic Languages". O., 2010. 18 p.

12. Kozhevnikova T. On the issue of linguistic imagology [K voprosu o lingvisticheskoy imagologii]. Foreign languages in high school. Ryazan, 2016. № 3 (38). P. 56-62.

13. Kubryakova O. To the definition of the concept of image [K opredeleniyu ponyatiya imidzha]. Issues of cognitive linguistics. 2008. № 1. P. 5-11.

14. Lozovskiy Yu. Language means of creating the image of a famous person: on the material of the media of Primorsky Territory [Yazyikovyie sredstva sozdaniya imidzha izvestnoy lichnosti: na materiale SMI Primorskogo kraya]: abstract of thesis for the $\mathrm{PhD}$ degree, spec. 10.02.01 "Russian language". Vladivostok, 2009. 24 p.

15. Lysychkina I. Lingvocommunicative mechanisms of forming the image of a law-enforcement organization [Linhvokomunikatyvni mekhanizmy formuvannia imidzhu pravookhoronnoi orhanizatsii]. Studia philologica. K., 2012. Issue. 1. P. 107-111.

16. Makarovets $\mathrm{Yu}$. Investigating a public person's image in linguistics [Doslidzhennia imidzhu publichnoi osoby u linhvistytsi]. Scientific notes of Nizhyn Gogol State University. Series: Philological Sciences. 2013. B. 3. P. 75-80.

17. Mogor-Ivan I., Priezler M. Some theoretical considerations on imagology. Language and literature. Annals of "Dunărea de Jos". University of Galati. Fascicle XIII. New Series. Issue 26. 2007. P. 69-74.

18. Moroz A. Color associations of Russians in relation to the English: lingvoimagological aspect (on the memoirs by M.V.Berg "Crimean notes") [Kolorovi asotsiatsii rosiian po vidnoshenniu do anhliitsiv: linhvoimaholohichnyi aspect (na materiali memuariv M.V. Berha "Kryimskie zametki")]. System and structure of the East Slavic languages: collection of scientific works. Kyiv, National Pedagogical Dragomanov University Publishing House. 2016. Issue 10. P. 199-207.

19. Osetrova E. On the definition of the concept of "language image" [K opredeleniyu ponyatiya "yazyikovoy imidzh"]. Language and social dynamics. Reshetnev Siberian State University of Science and Technology. Krasnoyarsk, 2012. № 12-1. P. 78-85. 
20. Ponomareva O. Verbalization of a political image in Russian and American media [Verbalizatsiya politicheskogo imidzha $\mathrm{v}$ rossiyskih i amerikanskih sredstvah massovoy informatsii]: abstract of thesis for the $\mathrm{PhD}$ degree, specialty 10.02.19 "Theory of Language". Volgograd, 2008. 23 p.

21. Postnikova L. Prosody and the political image of the speaker (on the material of the speeches of the American presidents) [Prosodiya $\mathrm{i}$ politicheskiy imidzh oratora (na material rechey amerikanskih prezidentov)]: abstract of thesis for the $\mathrm{PhD}$ degree, specialty 10.02.04 "German languages". M., 2003. 22 p.

22. Prokhorov A. Specificity of linguistic image modeling [Spetsifika lingvisticheskogo modelirovaniya imidzha]. TSU Bulletin. 2013. Vol. 9. P. 254-257.

23. Shnyakina E. Language means for forming the image of the leader of the region [Yazyikovyie sredstva formirovaniya imidzha lidera regiona]. Science of Energy: A collection of the VI International Scientific and Practical Internet Conference of Students and $\mathrm{PhD}$ Students. Yugra State University. Khanty-Mansiysk, 2016. P. 780-784.

24. Shylina A. Medialinguistic imageology and media linguistic imagology as the mesoparadigms of media linguistics [Medialingvoimidzhelogiya i medialingvoimagologiya kak mezoparadigmyi medialingvistiki]. Intercultural communications: scientific schools and modern areas of linguistic research: abstracts of reports of participants of an international scientific conference. Simferopol, April 19-20, 2016. P. 82-84.

25. Shylina A. The systemic status of media image (medialinguistic and cybernetic aspects) [Sistemnyiy status mediaimidzha (medialingvisticheskie i kiberneticheskie aspektyi)]. Advertising and public relations: traditions and innovations. Materials of the international scientific-practical conference. Rostov State Transport University, Rostovon-Don, 2016. P.78-83.

26. Shylina A. Media image supertext: stages of scientific comprehension [Mediaimidzhevyiy sverhtekst: etapyi nauchnogo osmyisleniya]. Advertising and public relations: traditions and innovations. Works of the fifth anniversary of the International Scientific and Practical Conference. Rostov State Transport University, Rostov-on-Don, 2017. P. 115-116.

27. Sidak O. Cognitive structure of the concept of "image" [Kohnityvna struktura poniattia "imidzh"]. Bulletin of Kharkiv National University named after V.N. Karazin. Kharkiv, 2009. № 837. P. 56-59.

28. Sushnenkova I. Lingvocognitive study of regional image [Lingvokognitivnoe issledovanie regionalnogo imidzha]: abstract of thesis 
for the PhD degree, spec. 10.02.19 "Theory of Language". Kemerovo, 2011. $27 \mathrm{p}$.

29. Tomberg O. Characteristic features of artistic images' linguistic representation in anglo-saxon poetic linguoculture. IX International Conference "Word, Utterance, Text: Cognitive, Pragmatic and Cultural Aspects". Future Academy, 2018. P. 590-596.

30. Yegorova L. Image text: lingvopragmatic and lingvocultural aspects (on the material of Russian-speaking journalism) [Imidzhevyi tekst: linhvoprahmatychnyi i linhvokulturolohichnyi aspekty (na materiali rosiiskomovnoi publitsystyky)]: abstract of thesis for the $\mathrm{PhD}$ degree, specialty 10.02.02 "Russian language". Simferopol, 2009. 20 p.

31. Zabolotna T. Linguistic foundations for creating Prince William's image in media texts [Linhvistychni osnovy stvorennia imidzhu pryntsa Viliama u mediatekstakh]. Theoretical and didactic philology. Issue 19, 2015. P. 191-200.

32. Zelenka M. A comparatist perspective in intercultural research and imagology. PORÓWNANIA XIX. 2016. P. 21-31.

\section{ЛІТЕРАТУРА}

1. Даулетова В. Вербальные средства создания автоимиджа в политическом дискурсе (на материале русской и английской биографической прозы) : автореф. дис. на соискание ученой степени канд. филол. наук : спец. 10.02.20 "Сравнительно-историческое, типологическое и сопоставительное языкознание". Волгоград, 2004. 16 с.

2. Фролова Е. Коммуникативные стратегии формирования имиджа регионального лидера. Культура народов Причерноморья. 2006. № 82. T. 2. C. 204-207.

3. Голошумова О. Роль интонации и других языковых средств в формировании и оптимизации имиджа политического лидера (на материале публичных выступлений американских политических деятелей) : автореф. дис. на соискание ученой степени канд. филол. наук : спец. 10.02.04 "Германские языки". М., 2002. 16 с.

4. Иванова Л. Европа в видении Н.С. Гумилева (лингвоимагологический аспект). Науковий бюлетень Херсонського державного університету. Серія "Лінгвістика". 2013. Вип. 18. С. 183-187.

5. Іванців О. Когнітивно-дискурсивні основи формування корпоративного іміджу (на матеріалі англомовних прес-релізів міжнародних косметичних компаній). Дисертація на здобуття наукового ступеня кандидата філологічних наук. Львів, 2015. 225 с. 
6. Камалова С. Имагологический образ палестинца в палестиноизраильском конфликте. Филологические науки в МГИМО. 2017. № 12 (4). C. 1-9.

7. Катынская М. Категория имиджа: подходы к рассмотрению. Теоретическая и прикладная лингвистика. Благовещенск, 2015. Том 1. № 3. С. 61-70.

8. Катынская М. Имидж как прототипическая категория. Вестник КГУ. 2016. №3.

9. Катынская M. Модель вербализованного имиджа австралийского образования. Современные проблемы взаимодействия языков и культур : материалы Междунар. форума 14-15 дек. 2012 г.: [в 2 ч.]. Благовещенск : Изд-во Амур. гос. ун-та, 2012. Ч. 1. С. 127-134.

10. Хайров Ш. Графика как объект лингвистической имагологии. О некоторых типах эстетических и идеологических оценок дореформенной кириллицы в России до и после 1918 г. Studi Slavistici XIV. 2017. C. 293-307.

11. Коваль Н. Просодичні іміджеві характеристики політичної ораторської промови (експериментально-фонетичне дослідження на матеріалі британського варіанту англійської мови) : автореф. дис. на здобуття наук. ступеня канд. філол. наук : спец. 10.02.04 "Германські мови". О., 2010. 18 с.

12. Кожевникова Т. К вопросу о лингвистической имагологии. Иностранные языки в высшей школе. Рязань, 2016. № 3 (38). С. 56-62.

13. Кубрякова Е. К определению понятия имиджа. Вопросы когнитивной лингвистики. 2008. №1. С. 5-11.

14. Лозовский Ю. Языковые средства создания имиджа известной личности : на материале СМИ Приморского края : автореф. дис. на соискание ученой степени канд. филол. наук : спец. 10.02.01 "Русский язык". Владивосток, 2009. 24 с.

15. Лисичкіна I. Лінгвокомунікативні механізми формування іміджу правоохоронної організації. Studia philologica. К., 2012. Вип. 1. C. $107-111$.

16. Макаровець Ю. Дослідження іміджу публічної особи у лінгвістиці. Наукові записки Ніжинського державного університету ім. Миколи Гоголя. Серія: Філологічні науки. 2013. Кн. 3. С. 75-80.

17. Mogor-Ivan I., Priezler M. Some theoretical considerations on imagology. Language and literature. Annals of "Dunărea de Jos". University of Galati. Fascicle XIII. New Series. Issue 26. 2007. P. 69-74.

18. Мороз А. Кольорові асоціації росіян по відношенню до англійців: лінгвоімагологічний аспект (на матеріалі мемуарів 
M.В. Берга "Крымские заметки"). Система i структура східнослов'янських мов : зб. наук. праць. Київ : Вид-во НПУ імені М.П. Драгоманова, 2016. Вип. 10. С. 199-207.

19. Осетрова Е. К определению понятия "языковой имидж". Язык и социальная динамика. Красноярск, 2012. № 12-1. С. 78-85.

20. Пономарева О. Вербализация политического имиджа в российских и американских средствах массовой информации : автореф. дис. на соискание ученой степени канд. филол. наук: спец. 10.02.19 "Теория языка". Волгоград, 2008. 23 с.

21. Постникова Л. Просодия и политический имидж оратора (на материале речей американских президентов) : автореф. дис. на соискание ученой степени канд. канд. филол. наук : спец. 10.02.04 "Германские языки". М., 2003. 22 с.

22. Прохоров А. Специфика лингвистического моделирования имиджа. Вестник ТГУ, 2013. Вып. 9. С. 254-257.

23. Шнякина Е. Языковые средства формирования имиджа лидера региона. Энергия науки: сборник VI Международной научнопрактической Интернет-конференции студентов и аспирантов. Югорский государственный университет. Ханты-Мансийск, 2016. C. $780-784$.

24. Шилина А. Медиалингвоимиджелогия и медиалингвоимагология как мезопарадигмы медиалингвистики. Межкультурные коммуникации: научные школы и современные направления лингвистических исследований: тезисы докладов участников международной научной конференции. Симферополь, 19-20 апреля 2016. С. $82-84$.

25. Шилина А. Системный статус медиаимиджа (медиалингвистические и кибернетические аспекты). Реклама и связи с общественностью: традиции и инновации. Материалы международной научно-практической конференции. Ростовский государственный университет путей сообщения, Ростов-на-Дону, 2016. С.78-83.

26. Шилина А. Медиаимиджевый сверхтекст: этапы научного осмысления. Реклама и связи с общественностью: традиции и инновации. Труды пятой юбилейной Международной научнопрактической конференции. Ростовский государственный университет путей сообщения, Ростов-на-Дону, 2017. С. 115-116.

27. Сідак О. Когнітивна структура поняття "імідж". Вісник Харківського національного університету імені В.Н. Каразіна. Харків, 2009. № 837. C. 56-59. 
Актуальні проблеми української лінгвістики: теорія і практика

28. Сушненкова И.

Лингвокогнитивное

исследование регионального имиджа: автореф. дис. на соискание ученой степени канд. филол. наук : спец. 10.02.19 "Теория языка". Кемерово, 2011. 27 с.

29. Tomberg O. Characteristic features of artistic images' linguistic representation in anglo-saxon poetic linguoculture. IX International Conference "Word, Utterance, Text: Cognitive, Pragmatic and Cultural Aspects". Future Academy, 2018. P. 590-596.

30. Сгорова Л. Іміджевий текст : лінгвопрагматичний i лінгвокультурологічний аспекти (на матеріалі російськомовної публіцистики) : автореф. дис. на здобуття наук. ступеня канд. філол. наук : спец. 10.02.02 "Російська мова". Сімферополь, 2009. 20 с.

31. Заболотна Т. Лінгвістичні основи створення іміджу принца Вільяма у медіатекстах. Теоретична і дидактична філологія. Вип. 19, 2015. C. 191-200.

32. Zelenka M. A comparatist perspective in intercultural research and imagology. PORÓWNANIA XIX. 2016. P. 21-31.

Дата надходження до редакції - 10.09.2018 р. Дата затвердження редакцісю - 26.10.2018 p.

УДК 811.161 .2

DOI: https://doi.org/10.17721/APULTP.2018.37.124-140

Чепорнюк A.B.

\section{ІНФОТЕЙНМЕНТ ЯК НЕОЖАНР МЕДІЙНОЇ КОМУНІКАЦЇ̈: ФУНКЦІОНАЛЬНО-СТИЛІСТИЧНИЙ АНАЛІЗ}

Анотація. Стаття присвячена функиіонально-стилістичному аналізу неожанру украйнських телевізійних новин - інфотейнменту. Доводиться теза, що ией жанр сьогодні існує та активно розвивається в украйнському медіапросторі, до того ж має ряд специфічних особливостей, властивих лише йому. На прикладі телепрограм "Абзаи!" на Новому каналі та "M1 News" на каналі M1 подається аналіз специфіки мовлення медійників у телепрограмах жанру інфотейнменту. "Інфотейнмент" (дослівно "infotainment 